\title{
CAUSES AND SCALE OF WINTER FLIGHTS IN HONEY BEE (APIS MELLIFERA CARNICA) COLONIES
}

\author{
Paweł Węgrzynowicz* \\ Dariusz Gerula \\ Małgorzata Bieńkowska \\ Beata Panasiuk
}

Research Institute of Horticulture, Apiculture Division, Kazimierska 2, 24-100 Puławy, Poland

*corresponding author: pawel.wegrzynowicz@man.pulawy.pl

Received 19 December 2013; accepted 17 April 2014

\begin{abstract}
Winter honey bee losses were evaluated during the two overwintering periods of $2009 / 2010$ and $2010 / 2011$. The research included dead bee workers that fell on the hive bottom board (debris) and the ones that flew out of the hive. Differences were observed in the number of bees fallen as debris between the two periods, whereas the number of bees flying out was similar in both years. No differences were found between the numbers of dead bees in strong and weak colonies. The percentage of bees flying out of the colony increased in the presence of Nosema spores, Varroa infestation, increased average air temperature, and insolation during the day. In addition, both the presence of Nosema and insolation during the day had an impact on the number of bees that died and fell on the hive board.
\end{abstract}

Keywords: bees fallen as debris, bees flying out in winter, colony overwintering, Nosema spp., Varroa destructor, winter losses of bees.

\section{INTRODUCTION}

Wintering is one of the critical times in honey bee colony existence, especially for weak or sick colonies, as they need to use more energy to maintain proper nest temperature compared to strong colonies. Thus, the lifespan of the colony considerably shortens, which can result in significant weakening, or even loss, of the whole colony. Varroa mite infestation and mistakes in apiary management (e.g., mismatched arrangement of frames, inadequate quality and quantity of forage) are believed to be the main causes of honey bee colony losses (Muszyńska, 1989; Topolska et al., 2008, 2009; Bieńkowska et al., 2012a, b; Costa et al., 2012).

The condition of bee colonies that survive the winter, as well as losing colonies, significantly affects the financial situation of apiaries and beekeepers directly. In additionally, an increasing overall deficit of bee colonies in Poland may have important economic and ecological consequences, including economic losses as a result of a lack of bees needed for entomophilous plant pollination. These losses are estimated to be approximately 2.5 - 3 billion PLN in Poland (Semkiw et al., 2007).

Worker bees produce heat and maintain the temperature in the nest after consuming carbohydrate food (Esch, 1960). With a decrease in temperature, weaker bees may become less active and fall down on the hive bottom board, forming winter debris. Therefore, the survival of the colony in winter depends on the number and condition of bees forming a winter cluster. However, worker bees falling to the hive bottom board during cold periods is not the only factor influencing winter bee losses. Bees may fly out of the hive on sunny but cold winter days, lose movement ability, and die, falling on the snow cover. Bees that fly out make up a significant percentage of the total winter bee losses (Witkiewicz et al., 2002; Romaniuk and Witkiewicz, 2005; Olszewski, 2007) and may even exceed the losses caused by bees falling on the hive bottom board (Węgrzynowicz et al., 2007; Wilde, 2008; Kasperek, 2012). Many hypotheses attempt to explain this behavior, but no studies explain this phenomenon clearly. According to Ostrowska (1985), diseased bees abandon 
the hive to protect the colony from pathogens, especially spores of Nosema spp., and more recent studies have corroborated that Nosema ceranae infection increases the flight activity of infected bees (Dussaubat et al., 2013). However, among the bees that fly out, many have been shown to be free of Nosema spores (Wilde, 2008). According to other researchers, this behaviour is related to the movements of bees in the winter cluster, relative air humidity inside the hive (Witkiewicz et al., 2002), or inappropriate winter forage (Ruciński, 2003).

The aim of the present study was to perform a comprehensive analysis of the phenomenon of winter bee flights to determine the factors affecting this behavior and evaluate their role.

\section{MATERIAL AND METHODS}

The research was performed at the apiary of the Research Institute of Horticulture, Apiculture Division, in Puławy. The study was conducted during two periods: 19 colonies were examined during the winter of 2009/2010 and 18 colonies during the winter of 2010/2011. Apis mellifera carnica, Marynka line, bees were kept and wintered in Dadant hives with combs perpendicular to the entrance. Strong and weak colonies were selected based on their populations. Two experimental groups were created for the comparison: a group of weak colonies with 3 - 4 combs occupied by bees and a group of strong colonies with 5 - 6 combs occupied by bees.

Before wintering, each colony was fed sugar syrup and varroa control treatments were conducted. In the first year, fumigation with Apiwarol A.S. (Amitraz
$12 \mathrm{mg} /$ tablet) was applied four times at 6 day intervals and a single trickling of $3.6 \%$ oxalic acid solution over the combs. In the second year, Bayvarol strips (flumethrin $3.6 \mathrm{mg} / \mathrm{strip}$ ) were applied in every colony for an 8-week period. The number of dead mites fallen on the hive bottom was recorded each week and Varroa destructor infestation level was assessed prior to the experiment. In autumn, shortly after establishing the winter clusters, samples of 20 bees were collected to determine the presence of Nosema spores.

Before wintering, paper sheets were placed on the bottom boards of the hives to collect dead bees and fallen varroa mites. The sheets also enabled an estimation of the area of the winter cluster section based on the area of the fallen debris (dead bees, varroa mites, and wax debris). The hive entrances were equipped with special entrance boxes with double-net walls to capture bees flying out and protect them from the birds.

The bees trapped in the entrance boxes and the bees on the hive bottom boards were collected from each colony every 14 days during the two wintering periods, counted, and examined for the presence of Nosema spores. The Varroa mites in the debris were also counted. The abdomens of 20 bees randomly chosen from each sample were crushed in a mortar with $20 \mathrm{~mL}$ of water. A drop of the macerate was used to prepare a smear on a slide and examined under the microscope at $\times 400$ magnification to determine the presence of Nosema spores. Data on the number of experimental colonies, observation periods, and number of collected bees are presented in Tab. 1

Table 1.

Scheme of the experiment

\begin{tabular}{|c|c|c|}
\hline \multicolumn{3}{|c|}{ Research year } \\
\hline Number of colonies & $2009 / 2010$ & $2010 / 2011$ \\
\hline Weak & 7 & 10 \\
\hline Strong & 12 & 8 \\
\hline Total & 19 & 18 \\
\hline Observation period & $8.12 .2009-16.03 .2010$ & $30.11 .2010-28.02 .2011$ \\
\hline $\begin{array}{l}\text { Number of time points for } \\
\text { sample collection }\end{array}$ & 7 & 6 \\
\hline $\begin{array}{l}\text { Number of samples collected } \\
\text { flying out of hive }\end{array}$ & 103 & 108 \\
\hline $\begin{array}{c}\text { Number of samples collected at } \\
\text { the hive bottom }\end{array}$ & 135 & 108 \\
\hline
\end{tabular}

The Tower number of samples collected for bees flying out of the hive in the first year of the experiment is related to the lack of bees at some sampling times. 
To exclude the influence of colony strength, the number of bees fallen on the bottom board and bees that flew out was converted to the number per one frame. Thus, an average number of bees fallen on the bottom board and flying out per comb was calculated. Similarly, the density of winter bee clusters was converted. The total area of the winter cluster section was divided by the number of combs occupied by bees in the wintering colony to determine the index of winter bee density.

Weather data were obtained from the meteorological station at The Institute of Soil Science and Plant Cultivation (IUNG), which is located approximately $1.5 \mathrm{~km}$ from the experimental apiary. The impact of the average air temperature, minimum and maximum air temperature, wind speed, air pressure, and insolation on bee behaviour and losses was analyzed.

Due to the lack of normal distribution of the data, non-parametric Mann-Whitney tests were used to evaluate the significance of differences between the analyzed factors. Pearson correlation coefficients were used to determine the interactions between analyzed factors, as well as the influence of some weather data on winter bee loss.

\section{RESULTS}

\section{Bee losses in wintering colonies}

In the winter of 2009/2010, the total losses averaged 352.6 bees per comb (from 203 to 629 bees), 3\% of which were bees flying out of the hive (average 9.6 bees). During the following winter, the total bee losses were significantly lower, ranging from 75 to 378 bees, an average of 199.2 bees per comb (Mann-Whitney Test, $U=45, p<0.05$ ). However, the percentage of bees flying out reached $8 \%$ of the total losses (13.2 bees). In both years, the main winter losses were bees collected from the debris. The number of bees fallen on the hive bottom board differed significantly between the periods (Mann-Whitney Test, $U=38, p<0.05$, Tab. 2). During the first winter period, significantly smaller winter debris was noted in the group of stronger colonies, but this was not seen in the second winter period. The number of bees flying out did not differ significantly in either group during any of the studied winter periods (Tab. 3).

Winter losses of bees

\begin{tabular}{|c|c|c|c|c|c|c|c|c|c|}
\hline \multirow[b]{2}{*}{$\begin{array}{l}\text { Winter } \\
\text { period }\end{array}$} & \multirow[b]{2}{*}{$\begin{array}{l}\text { Number of } \\
\text { colonies }\end{array}$} & \multicolumn{3}{|c|}{$\begin{array}{c}\text { Number of bees in winter } \\
\text { debris }\end{array}$} & \multicolumn{3}{|c|}{$\begin{array}{l}\text { Number of bees flying } \\
\text { out }\end{array}$} & \multicolumn{2}{|c|}{$\begin{array}{c}\text { Total winter be } \\
\text { losses }\end{array}$} \\
\hline & & Average & SD & $\begin{array}{c}\text { Average } \\
\% \text { of lost } \\
\text { bees to } \\
\text { total }\end{array}$ & Average & SD & $\begin{array}{c}\text { Average } \\
\% \text { of lost } \\
\text { bees to } \\
\text { total }\end{array}$ & Average & SD \\
\hline $2009 / 2010$ & 9 & $343 a$ & 109.5 & $97 \%$ & 9.6 a & 6.9 & $3 \%$ & $352.6 \mathrm{~b}$ & 112 \\
\hline $2010 / 2011$ & 8 & $186 b$ & 83.2 & $92 \%$ & $13.2 a$ & 6.2 & $8 \%$ & 199.2a & 84 \\
\hline Total & 37 & 264.5 & 125 & $95 \%$ & 11.4 & 6.7 & $6 \%$ & 275.9 & 125 \\
\hline \multicolumn{10}{|c|}{$\begin{array}{l}\mathrm{a}, \mathrm{b}-\mathrm{p} \leq 0.05 \\
\mathrm{SD}=\text { standard deviation. Data are given as per comb. }\end{array}$} \\
\hline \multirow{2}{*}{ Winter period } & \multirow{2}{*}{\multicolumn{2}{|c|}{ Winter bee losses }} & \multicolumn{4}{|c|}{ Number of bees/comb } & \multicolumn{3}{|c|}{ Mann-Whitney test } \\
\hline & & & Weel & k colonies & Strong cc & Dlonies & $U$ & $\mathrm{p}$-value & \\
\hline \multirow{2}{*}{ 2009/2010 } & \multicolumn{2}{|c|}{ Debris } & \multicolumn{2}{|c|}{ 415b } & \multicolumn{2}{|c|}{$301 a$} & 15 & 0.022 & \\
\hline & \multicolumn{2}{|c|}{ Flying out } & \multicolumn{2}{|r|}{9} & \multicolumn{2}{|c|}{10} & 32.5 & 0.44 & \\
\hline \multirow{2}{*}{ 2010/2011 } & \multicolumn{2}{|c|}{ Debris } & \multicolumn{2}{|r|}{184} & \multicolumn{2}{|c|}{189} & 39 & 0.96 & \\
\hline & \multicolumn{2}{|c|}{ Flying out } & \multicolumn{2}{|r|}{15} & \multicolumn{2}{|c|}{11} & 24 & 0.16 & \\
\hline \multirow{2}{*}{ Total } & \multicolumn{2}{|c|}{ Debris } & \multicolumn{2}{|r|}{279} & \multicolumn{2}{|c|}{256} & 157 & 0.7 & \\
\hline & \multicolumn{2}{|c|}{ Flying out } & \multicolumn{2}{|r|}{13} & \multicolumn{2}{|c|}{10} & 127 & 0.19 & \\
\hline
\end{tabular}

a, b - p $\leq 0.05$. Data are given as per comb. 
Varroa destructor mite infestation of colonies After the autumn 2009 treatment, Varroa mites that fell to the hive bottom boards were counted. The average number of $V$. destructor mites fallen per colony (autumn infestation) was 726.1 mites (from 97 to 2514), significantly higher (MannWhitney Test, $U=42, p \leq 0.05$ ) than the number counted the following year (from 10 to 772, the average 138.9 mites/colony). However, an influence of colony strength on $V$. destructor infestation was found only in 2009: 994.8 (from 10 to 2514) mites in strong colonies and 265.4 (from 14 to 772 ) mites in weak colonies (Tab. 4).

The natural Varroa mortality was $0.2 \%$ with respect to the autumn infestation in the first wintering period and $11.2 \%$ in the second period; the differences were significant in both years. However, no significant difference was found between weak and strong colonies for the combined data on mite infestation from both years (Tab. 4).
The experimental colonies were classified as weakly or strongly infected with the mite based on the number of $V$. destructor fallen as debris during autumn control treatments ( $\leq 255$ mites and $>255$ mites, respectively). The effect of the autumn varroa infestation on winter losses of bees was then analyzed. No direct relationship was found between the number of bees flying out and bees fallen as debris and the colony infestation level (Tab. 5).

The correlation analysis between the number of $V$. destructor mites in the bee colonies and the percentage of total winter bee losses attributed to bees flying out or falling to the bottom boards showed significant interrelation between these factors. The proportion of bees flying out with respect to total bee losses was lower in colonies with a greater autumn varroa infestation and increased with increasing numbers of mites found in the winter debris (Tab. 6).

Autumn Varroa destructor infestation levels

\begin{tabular}{ccccccc}
\hline & \multicolumn{2}{c}{ Period 2009/2010 } & \multicolumn{2}{c}{ Period 2010/2011 } & \multicolumn{2}{c}{ Total } \\
\hline $\begin{array}{c}\text { Colony } \\
\text { group }\end{array}$ & $\begin{array}{c}\text { Autumn } \\
\text { V. destructor } \\
\text { infestation } \\
\text { (No. of mites) }\end{array}$ & $\begin{array}{c}\text { Number of } \\
\text { V. destructor } \\
\text { mites in } \\
\text { winter debris }\end{array}$ & $\begin{array}{c}\text { Autumn } \\
\text { V. destructor } \\
\text { infestation } \\
\text { (No. of mites) }\end{array}$ & $\begin{array}{c}\text { Number of } \\
\text { V. destructor } \\
\text { mites in } \\
\text { winter debris }\end{array}$ & $\begin{array}{c}\text { Autumn } \\
\text { V. destructor } \\
\text { infestation } \\
\text { (No. of mites) }\end{array}$ & $\begin{array}{c}\text { Number of } \\
\text { V. destructor. } \\
\text { mites in } \\
\text { winter debris }\end{array}$ \\
\hline Strong & $994.8 \mathrm{~b}$ & $2.3 \mathrm{a}$ & $97.8 \mathrm{a}$ & $11 \mathrm{a}$ & $636 \mathrm{a}$ & 5.8a \\
\hline Weak & $265.4 \mathrm{a}$ & $0.6 \mathrm{a}$ & $173.4 \mathrm{a}$ & $19.5 \mathrm{a}$ & $211.3 \mathrm{a}$ & $11.7 \mathrm{a}$ \\
\hline Average & $726.1^{\star \star}$ & $1.7 \mathrm{~A}$ & $139.8^{\star}$ & $15.7 \mathrm{~B}$ & 440.8 & 8.5 \\
\hline
\end{tabular}

$\mathrm{a}, \mathrm{b}-\mathrm{p} \leq 0.05$ in relation to colony strength

$*^{* \star *}-p \leq 0.05$ between years for the autumn $V$. destructor infestation

$A, B-D \leq 0.05$ between years for $V$. destructor in winter debris

Table 5.

Winter bee losses in relation to the level of autumn $V$. destructor infestation

\begin{tabular}{cccc}
\hline $\begin{array}{c}\text { Autumn } \\
\begin{array}{c}\text { V. destructor infestation } \\
\text { (No. of mites) }\end{array}\end{array}$ & $\begin{array}{c}\text { Number of } \\
\text { bees flying out }\end{array}$ & $\begin{array}{c}\text { Number of bees } \\
\text { in winter debris }\end{array}$ & $\begin{array}{c}\text { Total winter } \\
\text { bee losses }\end{array}$ \\
\hline$\leq 255$ & 12.2 & 244.1 & 256.3 \\
\hline$>255$ & 10.5 & 290.5 & 301 \\
\hline Data are given as per comb. & & &
\end{tabular}

Data are given as per comb.

Table 6.

Correlation between winter bee losses and the number of Varroa destructor mites

\begin{tabular}{ccc}
\cline { 2 - 3 } & $\begin{array}{c}\text { Number of } V \text {. destructor mites } \\
\text { after autumn treatment }\end{array}$ & $\begin{array}{c}\text { Number of } V \text {. destructor } \\
\text { mites in winter debris }\end{array}$ \\
\hline $\begin{array}{c}\text { \% of bees flying out during } \\
\text { winter period }\end{array}$ & $-0.4^{*}$ & $0.49^{\star}$ \\
\hline $\begin{array}{c}\% \text { of bees fallen as debris } \\
\text { during winter period }\end{array}$ & $0.4^{\star}$ & $-0.49^{\star}$ \\
\hline
\end{tabular}

Pearson correlation coefficient; * $p \leq 0.05$ 
Nosema infection of colonies

The percentages of colonies infected with Nosema spores were similar in both years of the research: $39 \%$ in 2009 and $37 \%$ in 2010. The results were based on the autumn infection analysis. During both periods, a higher percentage of weak colonies were infected with Nosema spores than strong colonies; however, the differences were not significant (Fig. 1).

During the two winter periods, a total of 209 samples of bees flying out and 240 samples of bees fallen as debris were collected. Differences were found in the numbers of collected bees in relation to the presence of Nosema spp. In both years, the number of bees flying out from the colonies infected with
Nosema was significantly higher than in colonies lacking Nosema (Mann-Whitney Test, $U=593$, $\mathrm{p} \leq 0.05)$. No significant differences were found in the average number of bees fallen as debris on the bottom boards between the Nosema-infected and non-infected colonies. The number of infected bees was higher in samples collected during the first winter period compared to the second winter period (Tab. 7).

Influence of winter cluster density on bee losses The average area of the winter cluster section during the first overwintering period was $66 \mathrm{~cm}^{2} / \mathrm{comb}$ tightly covered by bees in the strong colonies, but in the group of weak colonies it was

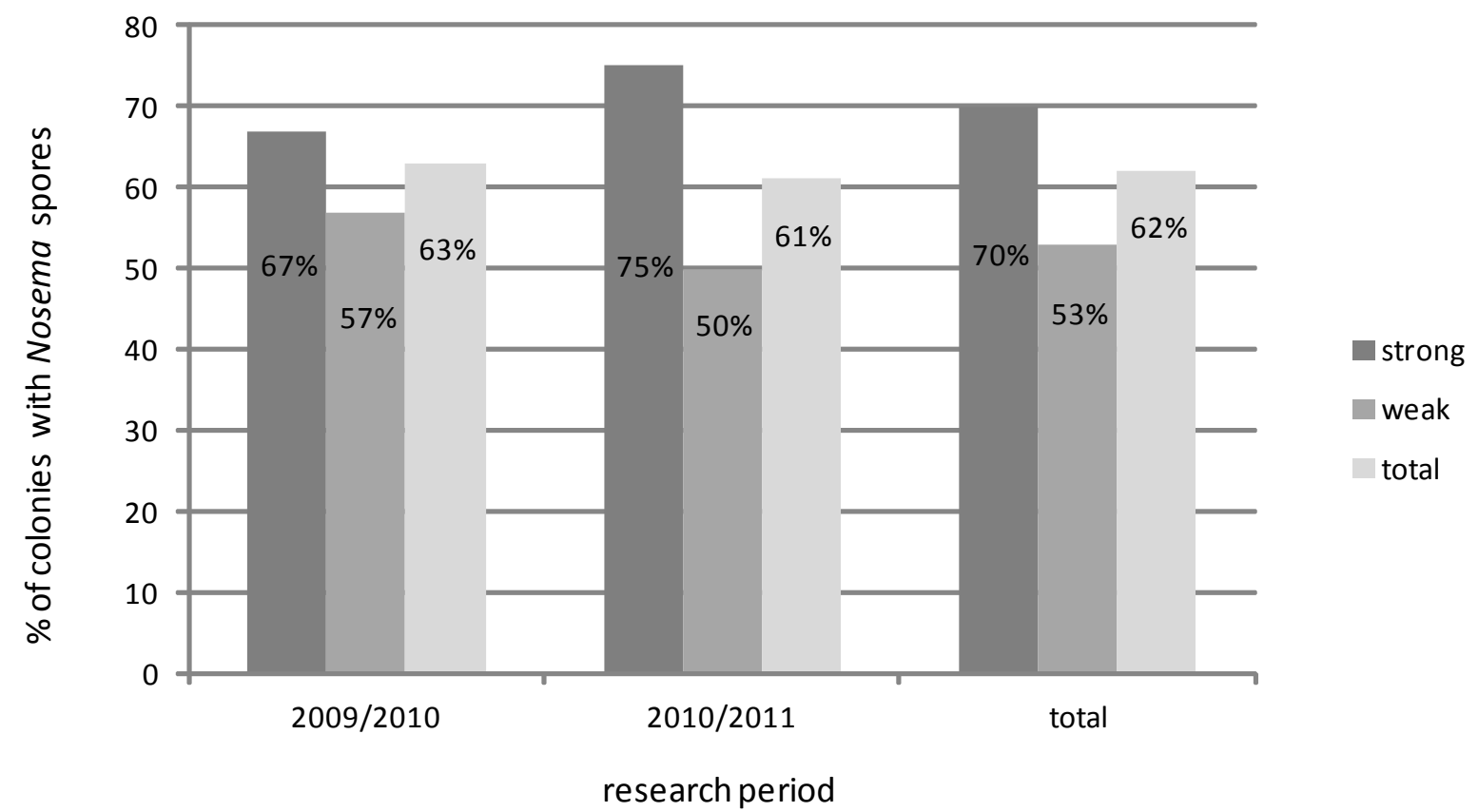

Fig. 1. Percentage of colonies containing Nosema spp.

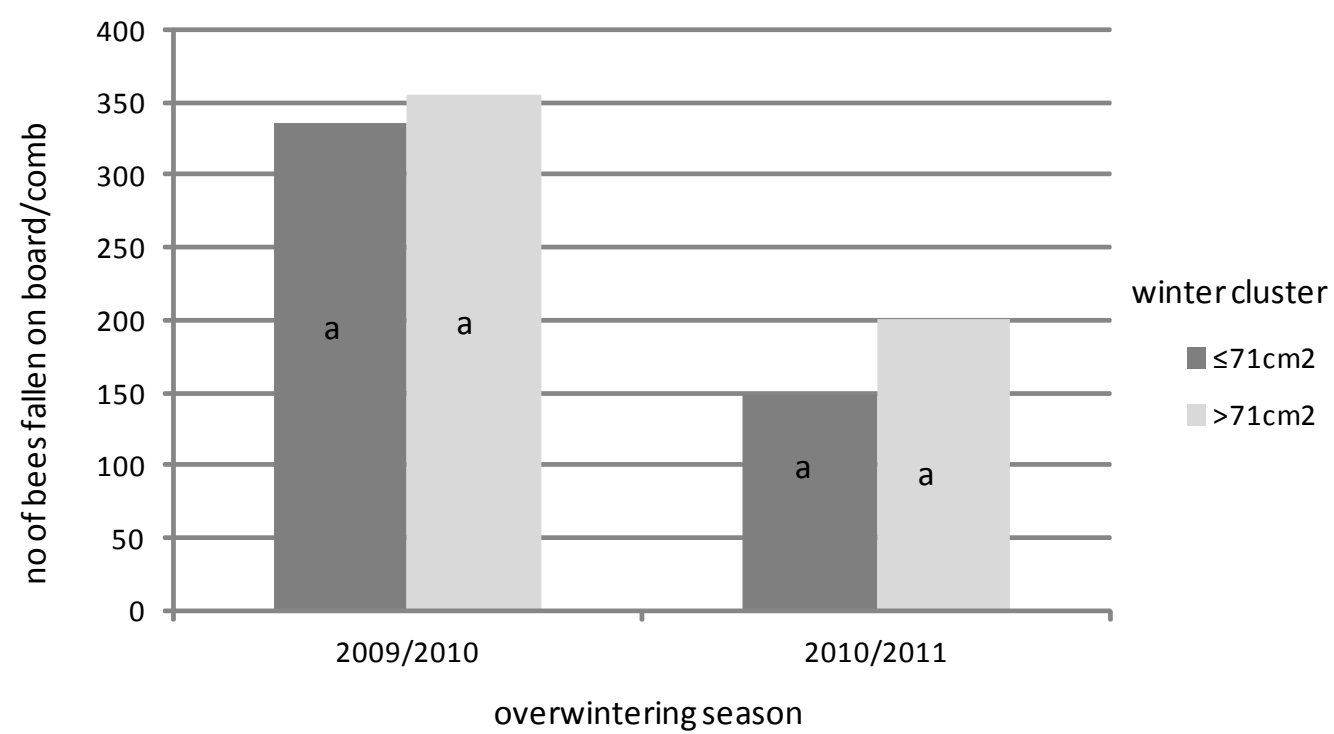

Fig. 2. Number of bees fallen to the hive bottom board in colonies with different cluster densities. 
$86 \mathrm{~cm}^{2} /$ comb. The differences were significant (Mann-Whitney Test, $U=17, p \leq 0.05$ ). During the next overwintering period, strong colonies occupied the combs more tightly than the weak colonies, but the differences were not significant.

Experimental bee colonies were grouped according to the winter cluster density: $\leq 71 \mathrm{~cm}^{2} /$ comb, colonies formed a tight cluster; $>71 \mathrm{~cm}^{2} /$ comb, colonies formed a loose cluster.

No correlation was found between the number of bees flying out and the number of bees in debris from individual colonies and the density of the winter cluster, but more bees were in the debris from colonies with loosely formed clusters in both study periods (Fig. 2).

A negative correlation was found between the autumn $V$. destructor infestation of colonies and the density of the winter cluster, with bee colonies forming tight clusters having significantly greater infestation. However, the cluster area had no significant effect on the number of mites found in the debris (Tab. 8).

\section{Weather conditions influencing winter bee loss}

Some weather factors were monitored during both overwintering periods. The average values for each 14-day period were calculated to compare the number of bees flying out and the number on the bottom board in relation to the weather conditions (Tab. 9). The correlation coefficients indicating the relationship between the weather conditions during both overwintering periods and bee losses are presented in Tab. 10. A significant positive correlation was found between the average air temperature and the number of bees flying out, whereas insolation influenced an increase in both the number of bees flying out and the number fallen on the hive board (Tab. 10). The number of bees flying out increased with increasing air temperature, whereas the number of bees on the bottom boards did not vary significantly.

\section{DISCUSSION}

Bee losses are recorded during every wintering period in all managed colonies as the number of bees in the debris on the bottom board and the number of bees flying out of the hive. Winter bee losses

Table 7.

The presence of Nosema spp. and number of bees in collected samples

\begin{tabular}{|c|c|c|c|c|c|c|c|}
\hline \multirow[b]{2}{*}{$\begin{array}{l}\text { Winter } \\
\text { loss of } \\
\text { bees }\end{array}$} & \multirow[b]{2}{*}{$\begin{array}{l}\text { Nosema spp. } \\
\text { in samples }\end{array}$} & \multicolumn{2}{|c|}{$2009 / 2010$} & \multicolumn{2}{|c|}{$2010 / 11$} & \multicolumn{2}{|c|}{ Total } \\
\hline & & $\begin{array}{c}\text { No. of } \\
\text { samples }\end{array}$ & $\begin{array}{c}\text { Average } \\
\text { number } \\
\text { of bees in } \\
\text { sample }\end{array}$ & $\begin{array}{c}\text { No. of } \\
\text { samples }\end{array}$ & $\begin{array}{l}\text { Average } \\
\text { number } \\
\text { of bees in } \\
\text { sample }\end{array}$ & $\begin{array}{c}\text { No. of } \\
\text { samples }\end{array}$ & $\begin{array}{c}\text { Average } \\
\text { number } \\
\text { of bees in } \\
\text { sample }\end{array}$ \\
\hline \multirow{2}{*}{$\begin{array}{c}\text { Flying } \\
\text { out }\end{array}$} & Not infected & 29 & $3.5 a$ & 4 & $3.0 a$ & 33 & $3.6 a$ \\
\hline & Infected & 72 & $10.6 b$ & 104 & 19.6b & 176 & $14.4 b$ \\
\hline \multirow{2}{*}{$\begin{array}{l}\text { Fallen on } \\
\text { the bottom } \\
\text { board }\end{array}$} & Not infected & 28 & $187.5 \mathrm{~A}$ & 8 & $235.6 \mathrm{~A}$ & 36 & $198.2 A$ \\
\hline & Infected & 104 & $241.2 B$ & 100 & $126 \mathrm{~B}$ & 204 & $184.8 A$ \\
\hline
\end{tabular}

$a, b-p \leq 0.05$ for flying out bees

$A, B-p \leq 0.05$ for bees fallen on bottom boards

Table 8.

Autumn Varroa destructor infestation and the number

of mites on the bottom boards in bee colonies with different cluster densities

\begin{tabular}{|c|c|c|c|c|c|c|c|c|c|c|c|c|}
\hline \multirow{2}{*}{$\begin{array}{c}\text { Surface of } \\
\text { comb occupied } \\
\text { by bees }\end{array}$} & \multicolumn{6}{|c|}{$\begin{array}{c}\text { Autumn V. destructor } \\
\text { infestation (after treatment) }\end{array}$} & \multicolumn{6}{|c|}{$\begin{array}{l}\text { V. destructor mites found } \\
\text { in winter debris }\end{array}$} \\
\hline & $\mathrm{N}$ & $09 / 10$ & $\mathrm{~N}$ & $10 / 11$ & $\mathrm{~N}$ & Total & $\mathrm{N}$ & $09 / 10$ & $\mathrm{~N}$ & $10 / 11$ & $\mathrm{~N}$ & Total \\
\hline$\leq 71 \mathrm{~cm}^{2}$ & 10 & 968.9 & 5 & 331.6 & 15 & 756.5b & 10 & 1.7 & 5 & 26 & 15 & 9.8 \\
\hline$>71 \mathrm{~cm}^{2}$ & 9 & 456.2 & 13 & 66 & 22 & 225.6a & 9 & 1.7 & 13 & 11.8 & 22 & 7.6 \\
\hline Total & 19 & 726.1 & 18 & 139.8 & 37 & 440.8 & 19 & 1.7 & 18 & 15.7 & 37 & 8.5 \\
\hline
\end{tabular}

$\overline{a, b-p \leq 0.05}$ 
Table 9.

The average values for weather conditions during the wintering periods

\begin{tabular}{ccc}
\cline { 2 - 3 } & $\begin{array}{c}\text { Period } \\
2009 / 2010\end{array}$ & $\begin{array}{c}\text { Period } \\
2010 / 2011\end{array}$ \\
\hline Average air temperature at $2 \mathrm{~m}\left({ }^{\circ} \mathrm{C}\right)$ & -4.7 & -3.0 \\
\hline Min temp at $2 \mathrm{~m}\left({ }^{\circ} \mathrm{C}\right)$ & -8.6 & -5.3 \\
\hline Max temp at $2 \mathrm{~m}\left({ }^{\circ} \mathrm{C}\right)$ & -1.1 & -0.2 \\
\hline Insolation $(\mathrm{h})$ & 3.4 & 2.9 \\
\hline Air pressure $(\mathrm{hPa})$ & 1001 & 998.9 \\
\hline Average wind speed $(\mathrm{m} / \mathrm{s})$ & 2.2 & 2.3 \\
\hline
\end{tabular}

Table 10.

The correlation coefficients for weather conditions and winter bee losses

\begin{tabular}{ccc}
\hline & $\begin{array}{c}\text { Number of bees } \\
\text { flying out/comb }\end{array}$ & $\begin{array}{c}\text { Number of bees } \\
\text { fallen on the } \\
\text { bottom board/comb }\end{array}$ \\
\hline Average air temperature at $2 \mathrm{~m}\left({ }^{\circ} \mathrm{C}\right)$ & $\mathbf{0 . 4 3 ^ { * }}$ & 0.14 \\
\hline Min temp at $2 \mathrm{~m}\left({ }^{\circ} \mathrm{C}\right)$ & $\mathbf{0 . 5 4 ^ { \star }}$ & 0.13 \\
\hline Max temp at $2 \mathrm{~m}\left({ }^{\circ} \mathrm{C}\right)$ & $\mathbf{0 . 4 6 ^ { * }}$ & 0.01 \\
\hline Amount of insolation $(\mathrm{h})$ & $\mathbf{0 . 3 6 ^ { * }}$ & $\mathbf{0 . 2 5 ^ { \star }}$ \\
\hline Air pressure $(\mathrm{hPa})$ & -0.18 & -0.19 \\
\hline Average wind speed $(\mathrm{m} / \mathrm{s})$ & -0.12 & -0.19 \\
\hline Pearson correlation coefficient; ${ }^{*} \mathrm{p} \leq 0.05$ & &
\end{tabular}

resulting from winter flights reached $3-5 \%$ of the total winter bee losses in present study, which is in line with previous studies (Witkiewicz et al., 2002; Romaniuk and Witkiewicz, 2005). However, the ratio of bees flying out and bees fallen as debris during winter depends on many factors, as previous studies (Olszewski, 2007; Węgrzynowicz et al., 2007; Kasperek, 2012) reported that the bees flying out exceeded $50 \%$ of the total winter losses. The present study shows for the first time that the ratio of bees flying out to bees fallen as debris does not depend on colony strength, although overall bee losses may be higher in weaker bee colonies.

Taking into account the sum of $V$. destructor mites collected after the autumn treatment and from the winter debris, the result was similar for strong and weak bee colonies. No correlation was found between winter bee losses and the level of autumn $V$. destructor infestation. These data do not confirm earlier reports (Dainat, 2012) claiming that diseases like varroatosis may shorten the lifespan of bees. However, an increase in natural mite mortality during the winter increased the number of bees flying out of the hive. This observation confirms the relationship between the presence of varroa mites in the hive during the winter and bees flying out $(r=0.49)$.
In the group of weak colonies, $53 \%$ of which were free from Nosema spores, the total number of V. destructor mites collected during the autumn anti-varroa treatment was significantly lower than in the group of strong colonies, $70 \%$ of which were free from Nosema spores. According to Botias et al. (2012), acaricides are less effective in colonies infected with Nosema spp. Thus, the reason for the lower number of mites collected from the debris in a group of weak colonies could have been the higher percentage of colonies infected with Nosema spores. This study reports for the first time the significant influence of Nosema spp. on the number of bees flying out and falling as debris on the bottom boards. Analysis of the presence of Varroa and Nosema during the winter indicated that these diseases significantly increase the percentage of bees flying out bees, but they did not seem to affect the overall loss of bees in our experimental conditions.

According to previous studies, some bee diseases shorten the lifespans of bees and induce bees to start performing risky tasks, such as flying out to collect water and forage earlier. Performing these tasks is a planned colony strategy that increases the chances of survival (Woyciechowski and Łomnicki, 1995; Woyciechowski and Kozłowski, 1998; Woycie- 
chowski et al., 1996; Tofilski, 2009). Bees flying out of the hive during the winter seem to be involved in a similar strategy to dispose of the pathogens from the wintering colony (Ostrowska, 1985).

The size of the winter cluster is closely related to the ambient temperature (Severson and Erickson, 1990), hive type, and the presence of pathogens in the nest (Büdel, 1959; Owens, 1971; Szabo, 1985; Severson and Erickson, 1990; Chuda-Mickiewicz et al., 1993). In the present study, the strength of the colonies and number of Varroa mites fallen after the autumn treatments significantly affected the density of bees in the winter cluster. However, colony strength did not significantly affect the natural winter fall of mites or the loss of bees flying out. In contrast to previous results (Witkiewicz et al., 2002; Romaniuk and Witkiewicz, 2005), no significant correlation has been found between the size of winter clusters and the number of bees fallen as debris or flying out, which was confirmed by Severson and Erickson (1990).

As the ambient temperature increased, the number of bees flying out of the hive significantly increased $(r=0.43)$. These results support previous findings (Witkiewicz et al., 2002; Romaniuk and Witkiewicz, 2005; Kasperek, 2012). However, Olszewski (2007) reported opposite results. In contradiction to the study by Kasperek (2012), no correlation was found between the ambient temperature and the number of bees dying during the winter. The abovementioned differences and the significant discrepancy between the percentage of bees flying out in winter and the total winter losses may be explained by using different types of hives in these two experiments. Kasperek (2012) used the Ostrowska hives made of polystyrene foam, and the current study used wooden Dadant hives with high hive bottoms. Studies indicate that the structure of the hive bottom influences the number of bees dying in the winter, and is related to hive ventilation (Skowronek and Skubida, 1995). Worse thermoregulation and bigger space between the nest and the hive entrance is assumed to cause more bees to fall to the hive bottom when trying to leave the hive. This concept is supported by the fact that some bees collected from hive bottoms wake up when kept at room temperature. Free and Spencer-Both (1960) also reported that single bees exposed to low temperature fell into comas lasting many hours. However, whether these were the bees that wanted to fly out of the hive or simply fell down to the hive bottom is difficult to determine.

\section{CONCLUSIONS}

The loss of bees due to winter flights was a small proportion (up to $8 \%$ ) of the total winter losses.

The proportion of bees flying in winter to the total losses of wintering bees did not depend on colony strength.

The presence of Varroa mites and nosemosis in wintering colonies significantly increased the percentage of bees flying out of the hive during this time, but it did not result in a significant increase in the total winter loss of bees.

An increase in ambient temperature results in a significant increase in the number of bees flying out of the hive.

\section{REFERENCES}

Bieńkowska M., Wilde J., Panasiuk B. (2012a) Losses of bee colonies in the GEl experiment in Poland. COLOSS Workshop Bee Book and data analyses of GEI experiment. MTT Jokoinen - Finland. 23 - 27 January 2012: 16-17.

Bieńkowska M., Gerula D., Węgrzynowicz P., Panasiuk B., Wilde J. (2012b) Przeżywalność rodzin pszczelich w pasiekach w których nie zwalczano pasożyta Varroa destructor. Materiały z XLIX Naukowej Konferencji Pszczelarskiej. Puławy - Poland. 13 - 14 March 2012: 50.

Botías C., Martín-Hernández R., Barrios L., Garrido-BailónE., Nanetti A., Meana A., Higes M. (2012) - Nosema spp. parasitization decreases the effectiveness of acaricide strips (Apivar ${ }^{\circledR}$ ) intreating varroosis of honey bee (Apis mellifera iberiensis) colonies. Environmental Microbiology Reports 4(1): 57-65. DOl:10.1111/j.17582229.2011.00299.x

Büdel R. (1959) En warm kupa sparar honung. Bitidningen 49(1): 5-7.

Chuda-Mickiewicz B., Prabucki J., Kostrzewa Z. (1993) Reakcja rodziny pszczelej na zmiany temperatury otoczenia. Pszczelnicze Zeszyty Naukowe 37: 51-63.

Costa C., Büchler R., Berg S., Bienkowska M., Bouga M., Bubalo D., Charistos L., Le Conte Y., Drazic M., Dyrba W., Fillipi J., Hatjina $F_{.,}$Ivanova E., Kezic N., Kiprijanovska $H_{.}$ Kokinis M., Korpela S., Kryger P., Lodesani M., Meixner M., Panasiuk B.,Pechhacker H., Petrov P., Oliveri E., Ruottinen L., Uzunov A., Vaccari G., Wilde J. (2012) A Europe-wide experiment for assessing the impact of genotype-environment interactions on the vitality and performance of 


\section{Ј. APPC. SCL. VOL. 58 N NO. 12014}

honey bee colonies: experimental design and trait evaluation. Journal of Apicultural Science 56(1): 147-158. DOl: 10.2478/v10289-012-0015-9

Dainat B., Evans J. D., Chen Y. P., Gauthier L., Neumann P. (2012) Dead or Alive: Deformend Wing Virus and Varroa destructor Reduce the Life Span of Winter Honeybees. Applied and Environmental Microbiology 78(4): 981 987. DOI: 10.1128/AEM.06537-11

Dussaubat C., Maisonnasse A., Crauser $D_{\text {., }}$ Beslay D., Costagliola G., Soubeyrand S., Kretzchmar A., Le Conte Y. (2013) Flight behavior and pheromone changes associated to Nosema ceranae infection of honey bee workers (Apis mellifera) in field conditions. Journal of Invertebrate Pathology 113(1): 42-51.

Esch H. (1960) Über die Körpertemperaturen und den Wärmehaushalt von Apis mellifica.Zeitschrift für Vergleichende Physiologie 43: 305-355.

Free J. B., Spencer-Booth Y. (1960) Chill-coma and cold death tem-peratures of Apis mellifera. Entomologia Experimentalis et Applicata 3: 222-230.

Kasperek K. (2012) Wpływ wybranych czynników atmosferycznych na straty pszczół miodnych (Apis mellifera) w okresie zimowym. Medycyna Weterynaryjna 60(10): 626-629.

Muszyńska J. (1989) Zimowanie pszczół. PWRiL. Warszawa. 39 pp.

Olszewski K. (2007) Winter-hardiness of Buckfast bees under specific weather conditions of areas with alternating influences of maritime and continental climate. Journal of Apicultural Science 51(1): 27-36.

Ostrowska W. (1985) Gospodarka pasieczna. PWRiL. Warszawa. 411 pp.

Owens C. W. (1971) The termology of wintering honeybee colonies. US Department Agricultural Technical Bulletin, Washington D.C. 1971, 1429: 1-32.

Romaniuk K., Witkiewicz W. (2005) Ocena pszczół opuszczających ul zimą. In: Materiały z XLII Naukowej Konferencji Pszczelarskiej. Puławy - Poland. 8 - 9 March 2005: 46-47.

Ruciński G. (2003) Zimowla rodzin pszczelich na miodzie z nawłoci. Pszczelarstwo 4: 21.
Semkiw P., Gerula D., Węgrzynowicz P. (2007) Pszczelarstwo w Polsce (część 1). Pszczelarswo 9: 12-14.

Severson D. W., Erickson E. H. (1990) Quantification of cluster size and low ambient temperature relationships in the honey bee. Apidologie 21: 135-142.

Skowronek W., Skubida P. (1995) Wpływ zwiększonej wentylacji gniazd pszczelich na przebieg zimowli rodzin. Pszczelnicze Zeszyty Naukowe 39(2): 15-26.

Szabo T. I. (1985) The thermology of wintering honey bee colonies in 4-colony packs as affected by various hive entrances. Journal of Apicultural Research 24(1): 27-37.

Tofilski A. (2009) Shorter-lived workers start foraging earlier. Insectes Sociaux 56: 359-366.

Topolska G., Gajda A., Hartwig A. (2008) Polish honey bee colony-loss during the winter of 2007/2008. Journal of Apicultural Science 52(2): 95-104.

Topolska G., Wilde I., Bober A., Semiw P., Bieńkowska M., Panasiuk B. (2009) Colony losses in Poland in the winter of 2007/2008. In: Proceedings of 4th COLOSS Conference. Zagreb - Croatia. 3 - 4 March 2009: 33-34.

Węgrzynowicz P., Olszewski K., Paleolog J. (2007) Wypryskiwanie pszczół - nieznany aspekt zimowli. Pszczelarstwo 9: 2-3.

Wilde J. (2008) Gospodarka pasieczna. In: Wide J., Prabucki J. (Eds.) Hodowla Pszczół. PWRiL. Poznań: 203-253.

Witkiewicz W., Romaniuk K., Witkiewicz A. (2002) Próba wyjaśnienia przyczyn wypryskiwania pszczół podczas zimowli. In: Materiały z XXXIX Naukowej Konferencji Pszczelarskiej. Puławy - Poland. 12 - 13 March 2002: 11-12.

Woyciechowski M., Kozłowski J. (1998) Division of labor by division of risk according to worker life expectancy in the honey bee (Apis mellifera L.). Apidologie 29: 191-205.

Woyciechowski M., Łomnicki A. (1995) Honey bee workers parasitized by Nosema apis choose riskier foraging strategies. Pszczelnicze Zeszyty Naukowe 39: 209-210.

Woyciechowski M., Kozłowski J., Grzanka G. (1996) Life expectancy and risk-taking in foraging honey bee workers. In: Proceedings of XX International Congress of Entomology. Firenze - Italy. 25 - 31 August 1996: 394. 